\title{
Oil Prices and the Macroeconomy
}

\author{
Lance Bachmeier \\ Michael Plante \\ June 5, 2018
}




\section{Introduction}

The combination of high inflation and high unemployment experienced in the 1970s and early 1980s has been perhaps the most important macroeconomic event since the Great Depression. Figure 1 shows that there were two spikes in the price of oil in this time period, and both were followed by large increases in inflation and unemployment. This was widely viewed as evidence that changes in the price of oil have large effects on the economy. Not surprisingly, this episode has been the subject of considerable research. ${ }^{1}$

More recently, as seen in Figure 2, the price of oil has been extremely volatile, but there has not been a corresponding increase in the volatility of either inflation or the unemployment rate. The post-1995 time period has witnessed the most stable inflation rate since the Great Depression, and the inflation rate fell to almost zero following the large increase in the price of oil in 2007 and 2008. Clearly something has changed since the 1970s and early 1980s. This has spurred renewed interest in oil prices and as a result the literature has been growing at a fast pace.

There have been two main approaches to answering the question 'What happens to the macroeconomy after an oil price shock?' 2 The first has been to estimate a vector autoregressive (VAR) model that includes a measure of energy prices and one or more macroeconomic variables. The motivation for using a VAR model is that it allows the researcher to estimate the effect of an oil shock without imposing strong assumptions about the structure of the economy, which reduces concerns about misspecification. Of course, there are costs associated with the use of a VAR model - efficiency may suffer when estimating many parameters, and there are some questions that simply cannot be answered with a VAR model. ${ }^{3}$ In addition, reliable identification of causal relationships can sometimes be tricky in VAR models.

The other approach has been to specify a dynamic stochastic general equilibrium (DSGE) model. These models are structural in nature and require the modeler to make explicit assumptions about the nature of the economy. The primary advantage of DSGE models over VAR models is that they can answer a wider range of questions, whether that is because VAR models are not designed to answer the question of interest, or because the VAR model would be too inefficient to provide a reliable answer. The downside of DSGE models is that one needs a considerable amount of information about the economy, including the process by which expectations are formed, consumer preferences, and price-setting behavior. And as a result of the large number of assumptions that

\footnotetext{
${ }^{1}$ The behavior of the macroeconomy following the oil shocks of the 1970s, and the inability of the macroeconomic models of the time to explain what was going on, led to a "major overhaul and reconstruction" of the field of macroeconomics (Blanchard (2006)).

${ }^{2}$ Although it is a valid question to ask about energy prices more generally, the literature has almost exclusively focused on oil prices due to its importance relative to other forms of energy. We follow suit with the literature.

${ }^{3}$ An example of a question VAR models are not designed to answer is determining which of several potential monetary policy responses to oil shocks will deliver the best combination of inflation and unemployment.
} 
need to be made, the nature of the answer one gets from a DSGE model may be constrained by those very assumptions. Our view is that researchers should understand and be prepared to use both methodologies.

The primary goal of this chapter is to provide the reader with an introduction to the published literature on the response of output to oil shocks and point out areas where work remains to be done. The chapter is organized into two broad parts, with the first focused on the empirical VAR literature and the second focused on DSGE models. Due to the large number of papers that have been published on this topic - some of which have been cited thousands of times - we focus on a small slice of the literature that we feel is most relevant for graduate students and other aspiring researchers. The review of the empirical literature focuses on works exploring the connection between oil prices and economic activity. We also provide a brief review of the empirical literature on the responses of inflation and consumption to energy price changes, but we do not discuss the response of financial variables such as stock prices, exchange rates, or measures of financial market volatility.

The DSGE section opens up by introducing an example of a simple DSGE model that incorporates oil. This provides some information about what those models look like and lets us discuss some issues related to calibration. We then use the example model to ask what happens to the economy when there is an unexpected increase in the price of oil due to some structural shock. The literature review focuses heavily on works exploring the connections between oil and economic activity, as well as papers on monetary policy responses to changes in oil prices. We briefly discuss other energy-related topics that have been looked at using DSGE models.

\section{Early Work}

The modern empirical literature on the relationship between oil prices and the macroeconomy started with Hamilton (1983). ${ }^{4}$ Hamilton motivated his investigation by noting that all but one recession after World War II was preceded by a large increase in the price of oil. The first row of Table 1 reports coefficients on the oil $_{t-i}$ terms in the regression

$$
y_{t}=\alpha+\sum_{i=1}^{4} \beta_{i} y_{t-i}+\sum_{i=1}^{4} \gamma_{i} o_{i} l_{t-i}+\varepsilon_{t}
$$

where $y_{t}$ is the percentage change in real GDP in quarter $t$ and $o i l_{t}$ is the percentage change in the wholesale price index for crude oil. ${ }^{5}$ For the time period 1960-1984, we reject the null hypothesis

\footnotetext{
${ }^{4}$ Other early papers include Rasche and Tatom (1977, 1981), Burbidge and Harrison (1984), and Hamilton (1985).

${ }^{5}$ This specification is taken from Hamilton (2003). The data used to estimate this regression can be found in the repository for this paper.
} 
that the change in the price of oil does not Granger cause real GDP growth at any conventional significance level $(p=0.007)$. The coefficients on the lagged oil price changes are negative and large, with a $10 \%$ increase in the price of oil reducing the forecast of GDP growth by about 0.4 percentage points in the fourth quarter after the shock hits the economy. ${ }^{6}$ Hamilton provided convincing evidence that the oil price changes in his sample could be treated as exogenous oil price fluctuations, which means the coefficients can be interpreted as the effect of an oil shock on the economy.

In contrast, the results for the 1985-2017 time period, also reported Table 1, offer less support for the claim that changes in the price of oil are an important source of output fluctuations. The estimated coefficients are still negative, but they are close to zero. A Wald test of the null hypothesis that the coefficients on the change in the price of oil are jointly equal to zero fails to reject $(p=0.52)$. One possible explanation for this finding is that the price of oil no longer affects the economy. That does not seem plausible, because energy still accounts for a non-trivial share of marginal cost and consumption expenditures in many industries. A more likely explanation is that a simple linear VAR model fails to properly capture the relationship between output growth and oil prices.

\section{Deviations From Linearity}

Shortly after the publication of Hamilton (1983), evidence began to accumulate that a linear model might provide a poor approximation of the relationship between output and the price of oil. Mork (1989) found that only oil price increases had a statistically significant effect on GDP growth. This had little effect within Hamilton's sample, because there were very few oil price decreases, but by the late 1980s the US had experienced large oil price decreases. ${ }^{7}$ Lee, Ni and Ratti (1995) and Ferderer (1996) found evidence that oil price volatility affected output. If oil price changes make it harder to predict the price of oil in the near future, there is an incentive for firms to delay investment and for consumers to delay major purchases, especially cars (see Bernanke (1983)). Oil price decreases can even be contractionary if they increase uncertainty about future oil prices, and as emphasized by Hamilton (1988), it takes time for workers to transition from the oil sector to other sectors.

Responding to Hooker (1996), Hamilton (1996) introduced the "net oil price increase" (NOPI) measure of oil price shocks. The idea is to construct a measure of oil shocks such that the price of oil only affects the economy during periods that it is high relative to recent experience, because those are the oil shocks that cause firms and consumers to change their behavior in a meaningful

\footnotetext{
${ }^{6}$ These results are similar to those reported by Hamilton (2003) for the period 1949-1980.

${ }^{7}$ One reason for this is that U.S. oil prices were regulated until the early 1980s (see e.g. Kilian (2014)).
} 
way. Hamilton (1996) defined NOPI to be

$$
N O P I_{t}=\max \left(0, \ln \left(\text { oil }_{t}\right)-o i l_{t}^{\max }\right)
$$

where oil $_{t}^{\max }$ is the natural $\log$ of the highest price of oil in quarters $t-1$ through $t-4$. Hamilton (2003) did a more rigorous investigation and concluded that it is best to compare the current price of oil against its highest price in the previous 12 quarters. Versions of the NOPI model have been estimated by Bernanke, et al (1997), Cuado and de Gracia (2003), Davis and Haltiwanger (2001), Balke, Brown and Yucel (2002), and Lee and Ni (2002), among many others.

In Table 2 are the estimated coefficients on the NOPI terms in the regression

$$
y_{t}=\alpha+\sum_{i=1}^{4} \beta_{i} y_{t-i}+\sum_{i=1}^{4} \gamma_{i} N O P I_{t-i}+\varepsilon_{t} .
$$

Although the coefficients estimated on the 1985-2017 subsample are smaller than those of the full 1960-2017 sample, the disappearance of the correlation between lagged oil price changes and real GDP growth does not carry through to the net oil price increase.

The hypothesis that oil price shocks have nonlinear effects on output has been challenged, most notably by Kilian and Vigfusson (2011a). Applying the simulation methodology proposed in Kilian and Vigfusson (2011b), they computed impulse response functions for real GDP growth for an oil shock that originated in the NOPI regime, and compared it with the impulse response function for the same shock originating in the non-NOPI regime. ${ }^{8}$ They tested and failed to reject the null hypothesis that the two impulse response functions were equal at all horizons up to one year, and concluded that the NOPI model is not supported by the data. Other authors, including Herrera, et al. (2011, 2015) and Herrera and Karaki (2015), applied the same test and also failed to reject the null hypothesis that the impulse response functions are the same across regimes.

Hamilton (2011) argued that there are several reasons to be skeptical of this conclusion. First, the failure to reject a null hypothesis is not evidence that the null hypothesis is true, and might instead be evidence that the test has low power. Second, Hamilton notes that Kilian and Vigfusson's test does reject linearity for large (two standard deviation) oil shocks. Moreover, using the local projections method for computing impulse response functions introduced by Jord (2005), Hamilton rejects the null hypothesis of linearity for every model specification. Finally, working with just a prediction equation for GDP, which can be interpreted as one equation in a reduced form VAR model, Hamilton rejects the null hypothesis that all coefficients on the lagged NOPI terms are zero. It is difficult to reconcile these results with the claim that a linear VAR model provides the

\footnotetext{
${ }^{8}$ The impulse response functions in a nonlinear model will depend on the choice of the initial state of the economy and the size and sign of the shock. In a linear VAR model, the impulse response functions are constant.
} 
best representation of the data. Hamilton (2016) points out that all of the studies that fail to find evidence of nonlinearity rely on the Kilian and Vigfusson (2011b) test. Given the disagreements, and given this topic's importance, it is sure to be the subject of additional research in the future.

An alternative to the NOPI model, which retains the property that the price of oil only affects the economy when it deviates substantially from its behavior in the recent past, is the net oil price change (NOPC) model proposed by Kilian and Vigfusson (2013). Define the net oil price decrease as

$$
N O P D_{t}=\min \left(0, \ln \left(o i l_{t}\right)-o i l_{t}^{\min }\right)
$$

where oil $_{t}^{\text {min }}$ is the natural log of the lowest price of oil in the previous 12 quarters. We then have

$$
N O P C_{t}=N O P I_{t}+N O P D_{t}
$$

One of the advantages of the NOPC model over the NOPI model is that there are fewer censored observations of the oil price, which should result in more efficient parameter estimates, as well as less bias, if oil price decreases affect the economy. Similar to the NOPI model, the NOPC model allows for nonlinearity, but it rules out asymmetry. Kilian and Vigfusson considered a variety of alternative specifications, including those in which the NOPD and NOPI variables have different coefficients, but concluded that the NOPC model provides the best out-of-sample output forecasts out of all nonlinear models that they considered. Other out-of-sample forecast evaluations

of nonlinear oil price models include Bachmeier, et al (2008) and Ravazzolo and Rothman (2011), and Kilian and Vigfusson (2017).

\section{Endogeneity of Oil Prices}

One of the important findings of Hamilton (1983) was that changes in the price of oil could be interpreted as supply shocks. In the aftermath of the oil shocks of the 1970s, which were attributed to the OPEC oil embargo and the Iranian revolution, this was a reasonable conclusion. It should be noted, however, that it has long been recognized that the price of energy responds to changes in the economy. In a speech to Congress on June 4, 1971, President Nixon said, ${ }^{9}$

During the last decade, the prices of oil, coal, natural gas and electricity have increased at a much slower rate than consumer prices as a whole. Energy has been an attractive bargain in this country-and demand has responded accordingly. In the years ahead, the needs of a growing economy will further stimulate this demand.

\footnotetext{
${ }^{9}$ http://www.presidency.ucsb.edu/ws/?pid=3038
} 
One cannot provide a useful answer to the question, 'What happens to output if the price of oil rises?' without knowing why the price of oil has risen. Macroeconomic theory predicts lower output if the price of oil has risen because of a shock to the supply of oil. On the other hand, output will obviously be higher if the price of oil has risen because the economy (and therefore the demand for oil) is growing faster than expected. A third possibility is that the demand for oil is rising because of higher foreign output, in which case the response of domestic output depends on whether the expansionary effect of increased exports is sufficient to offset the contractionary effect of the higher oil price. One cannot interpret an estimated relationship between output and the price of oil without first addressing the endogeneity of oil prices.

An important step toward solving this identification problem was made by Kilian (2009). ${ }^{10}$ The key component in Kilian's analysis was the construction of an index of global economic activity based on shipping rates. In the short run, there is a ceiling on the quantity of goods that can be shipped due to lags in the production of new shipping capacity, causing periods of unexpectedly strong world economic growth to be accompanied by increases in shipping rates. Kilian estimated a VAR model with global crude oil production, real oil prices, and his constructed index of global economic activity, and identified three structural shocks, interpreted as "oil supply", "aggregate demand", and "precautionary demand" shocks. The oil supply and aggregate demand shocks have a straightforward interpretation. The precautionary demand shock represents an increase in purchases due to concerns about the future availability of oil, such as an airline purchasing additional jet fuel after news about a possible disruption of oil supplies, even if current oil production has not yet been affected.

Kilian concluded that the price of oil has historically been driven almost entirely by the aggregate demand and precautionary demand shocks, with oil supply shocks playing only a minor role. This should not be interpreted as a statement that the supply of oil is unimportant to the determination of oil prices, because the precautionary demand shock captures the effect of news about the supply of oil that has not yet affected global oil production.

Recent work has shown that decomposing oil price movements into the parts corresponding to oil supply shocks and oil demand shocks depends critically on assumptions about the short-run elasticity of oil supply. Caldara, Cavallo, and Iacoviello (2016) propose an identification scheme that forces the elasticities implied by a VAR model to be consistent with the elasticities reported in published papers. They conclude that oil supply shocks explain $50 \%$ of the variation in the price of oil, while global economic activity shocks explain only 30\%. Baumeister and Hamilton (2017) adopt a Bayesian approach to inference that is less restrictive than the traditional approach

\footnotetext{
${ }^{10}$ Barsky and Kilian (2001) was an earlier paper that questioned the interpretation of oil price movements as oil supply shocks, but Kilian (2009) has been the foundation of much of the subsequent literature. See also Lippi and Nobili (2012), Peersman and Van Robays (2012), and Aastveit (2014).
} 
to VAR model identification. ${ }^{11}$ The reported posterior distributions imply a non-zero short-run oil supply elasticity that they report is much larger than the upper bound of Kilian and Murphy (2012), for instance. Their findings suggest that the assumption that oil production is almost completely unresponsive to market conditions in the short run is a mistake. Baumeister and Peersman (2013) address a related problem by estimating a VAR model with time-varying parameters and stochastic volatility. They show that the assumption of constant VAR coefficients can make it difficult to properly identify the effects of oil supply and oil demand shocks on the economy.

An additional complication arises if one treats all oil price movements that are responses to the economy as a single shock. By construction, the price of oil and U.S. real GDP growth will be positively correlated if the price of oil is changing as a response to U.S. output. That will not necessarily be true when the price of oil is responding to foreign output shocks. In the extreme case in which the foreign economy does not trade with the U.S., output in the U.S. will respond in the same way as it responds to an oil supply shock. ${ }^{12}$ Aastveit, et al. (2015) found that most oil price fluctuations since the early 1990s could be attributed to changes in demand in emerging and developing economies. Thus, even if one adopts the view that the price of oil is largely driven by demand shocks, higher oil prices may still be a drag on U.S. economic growth.

High frequency data has been used to aid the identification of contemporaneous responses. Kilian and Vega (2011) study news about U.S. macroeconomic data releases and conclude that energy prices can be treated as predetermined with respect to the U.S. economy. Bachmeier (2013) is unable to reject the hypothesis that world oil prices are predetermined with respect to U.S. gasoline prices. To the extent that gasoline price fluctuations reflect shocks to U.S. economic activity, this is additional evidence that energy prices respond to macroeconomic shocks with a lag.

\section{Gasoline Prices and Consumption}

One mechanism by which oil shocks are transmitted to the economy is through retail gasoline prices. Higher gasoline expenditures have to be offset by reduced consumption of other goods. This effect has been verified by Edelstein and Kilian (2009), Farrell and Greig (2015), Gelman, et al. (2016), and Baumeister and Kilian (2016). One of the important outstanding research questions is how much this effect has changed over time. Edelstein and Kilian (2009), Ramey (2016) and Baumeister, et al. (2017) have investigated this question, with Baumeister, et al. arguing that changes in the relative importance of oil supply and oil demand shocks will cause the estimated

\footnotetext{
${ }^{11}$ The traditional approach imposes numerical values for some of the parameters and assumes no knowledge about the others, and can be represented as a special case of the approach used by Baumeister and Hamilton (2017).

${ }^{12}$ Blanchard and Gali (2009) use a similar argument to justify their empirical methodology.
} 
responses of consumption to fluctuate. Sorting through these issues is a difficult task, but one of great importance, as it is impossible to accurately predict changes in consumption without doing so.

\section{Monetary Policy}

VAR analysis, which most commonly takes the form of impulse response function analysis, does not provide any information about the mechanisms by which oil shocks are transmitted to the economy. In addition to the direct effect that oil shocks have on the economy through production and consumption, oil shocks will indirectly affect the economy through monetary policy if the Federal Reserve responds to them in an attempt to stabilize output and inflation. Bernanke, et al. (1997) simulated the behavior of the U.S. economy using an estimated VAR model combined with various choices of the monetary policy rule. They concluded that "... the monetary policy response is the dominant source of the real effects of an oil price shock."

The conclusion drawn by Bernanke, et al. (1997) that monetary policy is responsible for much of the response of the economy to an oil shocks has not been universally accepted. One problem, recognized by the authors, is that their analysis ignores the Lucas (1976) critique. Sims (1997) questioned the choice of alternative monetary policy rule on the grounds that it is unsustainable. Hamilton and Herrera (2004) argue that implementing the alternative monetary policy rule would have required implausibly large changes in the federal funds rate. In addition, even if one assumes the Federal Reserve would have been capable of implementing such a policy, their conclusion is not robust to the use of longer VAR lag lengths. Kilian and Lewis (2011) provided additional evidence against the importance of monetary policy for the effects of oil shocks, most notably by demonstrating that the Federal Reserve has not responded to oil shocks at all since at least the mid1980s. Other relevant papers that we will not discuss here include Bohi (1989), Barsky and Kilian (2002), Carlstrom and Fuerst (2005), Herrera and Pesavento (2009), and Bodenstein, Guerrieri, and Kilian (2012).

Due to the limitations of VAR models, we feel that DSGE models are better able to provide insights on the relative importance of the monetary policy rule. DSGE models are designed to address questions like this, and in fact, they have been used by many central banks for this purpose (Gal and Gertler (2007)). We anticipate that most future research on the interaction of oil shocks and monetary policy will be done using DSGE models. 


\section{Oil Shocks and Inflation}

Macroeconomic models imply that an increase in the price of oil will cause inflation to rise. A surprising finding highlighted by Hooker (2002) is that core inflation shows little or no response to oil price shocks. Clark and Terry (2010) estimated a time-varying parameter VAR model and found that the decline in the response of core inflation to oil shocks began in 1975, and that this was not affected by either the high volatility of oil prices in the early 2000 s or changes in the Federal Reserve's monetary policy rule. de Gregorio, Landeretche, and Neilson (2007) and Chen (2009) looked at inflation in many different countries and found a similar decline.

Attempting to understand the reason for the decline, Blanchard and Gal (2009) found support for three potential explanations. First, wages have become more flexible through time, which allows the higher cost of production resulting from an oil shock to be partially offset by lower wages, which puts less pressure on inflation. Second, the credibility of monetary policy has improved, causing all inflationary shocks to have less effect on inflation. Third, energy is a smaller part of the economy today than it was in the 1970s. Bachmeier and Cha (2011) used disaggregate inflation data to sort through the relative importance of these explanations. They found that most of the decline in the response of inflation to oil shocks took place in sectors that saw large declines in energy intensity, and by itself, the change in energy intensity can predict most of the change in the response of aggregate inflation to an oil shock. Additonally, they found little correlation between the labor intensity of a sector and the change in response to oil shocks. See Blinder and Rudd (2012) and Castro, Jerez and Barge-Gil (2016) for additional analyses.

\section{DSGE Models}

Dynamic stochastic general equilibrium (DSGE) models provide an internally consistent modeling framework for thinking about energy prices and the economy. Since the early works of Hamilton (1988) and Kim and Loungani (1992), a number of papers have been published that make use of DSGE models with energy. These have primarily considered oil, as opposed to other forms of energy, and have explored the importance of oil and oil prices for issues related to business cycles, monetary policy and many other topics.

In this chapter, we introduce a very simple DSGE model that incorporates oil and provide a review of the DSGE literature. One of our main goals in introducing the model is to provide a working example that goes through the model's equations and discusses several issues related to calibration. As an aide to the interested reader, an online appendix provides additional details regarding several variants of the model and further discussion on issues related to incorporating oil into DSGE models. The associated Matlab code is also posted online. 
Another goal is to use the model to investigate the theoretical relationship between oil prices and economic activity. To do this, we solve the model numerically and look at how oil prices and GDP respond to different structural shocks in the model. We highlight the importance of distinguishing between supply and demand shocks in the oil market as not every type of shock generates the same correlation between oil prices and economic activity. In particular, while oil supply shocks generate a negative correlation, other shocks need not do so.

Not surprisingly, a large literature exists that makes use of DSGE models to think about various issues related to oil and the economy. The literature review at the end of this section provides a number of references for those interested in learning more about specific topics. The review focuses primarily on works that discuss how oil can affect the economy (and vice-versa), and works that explore monetary policy issues that arise because of oil and oil prices. We hope this review will be a useful starting point for those interested in learning more about the existing research.

\subsection{Model}

DSGE models are structural in nature require explicit assumptions about the structure of the economy. ${ }^{13}$ When incorporating oil into a DSGE model this means that several questions must be answered in advance by the modeler. These include: Are oil prices exogenous or endogenous? Does the economy produce oil or not? If so, how much and how is that production modeled? What sectors of the economy use oil? How is that use modeled?

In our model, we make the following assumptions. First, since we are interested in discussing how different shocks affect oil prices and economic activity, we need endogenous oil prices. However, we do not need to go beyond the simple assumption that the supply of oil is exogenous. Second, we consider an economy that imports all of its all from abroad but we do not explicitly model the rest of the world except with regards to oil production. Finally, for simplicity we assume oil is used as an input into the production of a final good but abstract from household use of oil. These assumptions make the model very similar to the one used in Kim and Loungani (1992), except that oil prices are endogenous in our setup.

We work with a decentralized model with a representative agent and a representative firm. The representative agent consumes a final good and earns income by providing labor to the private sector and from dividends it receives from the firm. The representative firm operates under perfect competition and produces the final good using labor and imported oil. Each period the economy in question trades some of its output of the final good for oil. The model assumes that trade balances each period.

\footnotetext{
${ }^{13}$ It is beyond the scope of this chapter to provide a detailed introduction to DSGE models. See McCandless (2008) for a nice introduction to both Real Business Cycle models and New Keynesian models.
} 
The representative agent chooses consumption and labor to maximize the present discounted value of utility,

$$
E_{0} \sum_{t=0}^{\infty} \beta^{t}\left[\log \left(c_{t}\right)-\chi n_{t}^{1+\eta} /(1+\eta)\right],
$$

where $\beta$ is the discount factor, $c_{t}$ is consumption, $n_{t}$ is hours worked, $\eta$ is the inverse Frischelasticity of labor and $\chi$ is the weight on the dis-utility from working. Utility is maximized subject to a budget constraint,

$$
c_{t}=w_{t} n_{t}+d_{t}
$$

where $w_{t}$ is the real wage and $d_{t}$ are dividends from the firm. The household takes prices and wages as given when making its decisions.

Denoting $\lambda_{t}$ as the multiplier on the budget constraint, the first-order conditions are given by

$$
\begin{gathered}
1 / c_{t}=\lambda_{t}, \\
w_{t} \lambda_{t}=\chi n_{t}^{\eta},
\end{gathered}
$$

which can be combined into a single equation, $w_{t}=\chi n_{t}^{\eta} c_{t}$.

The representative firm maximizes profit by choosing the amount of labor and oil to be used in the production of the final good, $y_{t}$. The technology available to the firm is a CES production function of the form

$$
y_{t}=\left[\left(1-\alpha_{o}\right)\left(n_{t} z_{t}^{n}\right)^{\frac{\sigma-1}{\sigma}}+\alpha_{o}\left(o_{t} z^{o}\right)^{\frac{\sigma-1}{\sigma}}\right]^{\frac{\sigma}{\sigma-1}},
$$

where $o_{t}$ is oil used by the firm and $z_{t}^{n}$ is a labor-augmenting productivity shock. The term $z^{o}$ is, in this case, a constant scaling factor but one can easily make it stochastic to represent exogenous shocks that affect the efficiency with which the private sector uses oil as an input.

Introducing oil into the production function adds two parameters that are not present in the basic RBC model. The first is $\alpha_{o}$, which controls the cost-share of oil in gross output, $y_{t}$. The second parameter is $\sigma$, which is the elasticity of substitution between oil and labor (or valueadded). The exact nature of these parameters can vary across models. In Kim and Loungani (1992), for example, the elasticity parameter controls the degree of substitutability between capital and energy.

The first-order conditions for the firm are given by

$$
\begin{gathered}
w_{t}=\left(1-\alpha_{o}\right)\left(\frac{y_{t}}{n_{t}}\right)^{\frac{1}{\sigma}} z_{t}^{n \frac{\sigma-1}{\sigma}} \\
p_{t}^{o}=\alpha_{o}\left(\frac{y_{t}}{o_{t}}\right)^{\frac{1}{\sigma}} z^{o \frac{\sigma-1}{\sigma}}
\end{gathered}
$$


For the oil market, we assume there is a stochastic endowment of oil whose ownership lies outside the domestic economy. The log supply of oil follows an autoregressive process,

$$
\ln o_{t}^{s}=\left(1-\rho_{s}\right) \ln o^{s}+\rho_{s} \ln o_{t-1}^{s}+\sigma_{s} \epsilon_{s, t} .
$$

The market clearing condition for the oil market is given by

$$
o_{t}=o_{t}^{s}
$$

One can derive a resource constraint for the economy using the household's budget constraint and the firm's first order conditions. The resource constraint for the economy is

$$
c_{t}=y_{t}-p_{t}^{o} o_{t}
$$

It is useful to note that in this model there is a difference between gross output and GDP/valueadded and that there are several ways one can measure GDP. By the expenditure approach, real GDP is simply equal to $c_{t}$. Another way is to measure value-added from the final goods sector, which mathematically is equal to $y_{t}-p_{t}^{o} o_{t}$ and which is equivalent to $c_{t}$. Gross Domestic Income could also be calculated as $w_{t} n_{t}$.

Finally, we need to specify a law of motion for productivity. We assume the log of laboraugmenting productivity follows an autoregressive process,

$$
\ln z_{t}^{n}=\left(1-\rho_{n}\right) \ln z^{n}+\rho_{n} \ln z_{t-1}^{n}+\sigma_{n} \epsilon_{n, t} .
$$

\subsection{Calibrating the steady state}

Typically, a DSGE model is linearized and solved using numerical methods. This requires calibrating or estimating the model's parameters and choosing steady state values for the variables. Our calibration approach here is illustrative and intended to provide a short discussion on some of the issues that arise because the model incorporates oil.

The model has nine parameters that need to be calibrated: $\beta, \alpha_{o}, \eta, \chi, \sigma, z^{o}, \rho_{s}, \rho_{n}, \sigma_{s}$ and $\sigma_{n}$. Starting values also need to be chosen for $w, y, c, p^{o}, z^{n}, o^{s}$ and $o$. We drop the time subscript to denote a steady state value.

The parameters $\beta, \eta$ and $\chi$ are not unique to models with oil so we do not discuss their calibration in detail. We calibrate the model to be consistent with a quarterly frequency. We set the discount factor $\beta$ to 0.99 , labor-supply elasticity $\eta$ to 1 and determine the value of $\chi$ by using the

household's first order condition for labor. For simplicity we set all persistence parameters for the 
shocks equal to 0.90 and all standard deviations to $0.001 .^{14}$

The parameter $\sigma$ is directly connected with the price-elasticity of demand for oil. Numerous estimates exist for this price-elasticity but a generally accepted finding is that short-run price elasticities for oil are low, i.e. well below unity. As a result, this parameter (or a related parameter) is also typically set well below 1 . For illustrative purposes, we consider a value of 0.25 .

One approach to calibrate $\alpha_{o}$ is to use data on the cost-share of oil or a related quantity, such as the GDP-share of oil. For the U.S., there is annual data available to help provide some guidance on what this number should be set to. Data on nominal spending on petroleum products is available from the U.S. Energy Information Administration (EIA) from 1970 to 2015. ${ }^{15}$ This covers spending by both firms and households. Another set of data from the Bureau of Economic Analysis (BEA) provides annual nominal spending by households on motor gasoline, heating oil and other fuels. ${ }^{16}$ This can be subtracted off from the EIA data to produce an estimate of nominal spending by firms on petroleum products. Nominal GDP data comes from the BEA.

Figure 3 plots the time series for the ratio of nominal oil expenditures to nominal GDP for firms and households. One notable feature is that both shares vary over time. This variation is connected with the price of oil and has to do with the fact that the demand for oil is relatively inelastic. As a result, a large swing in oil prices can dramatically affect nominal expenditures. Another feature is that both shares have remained below the high values seen in the mid-1970s and early 1980s, even during recent period where oil prices were relatively high. This has to do with the fact that the economy has become less oil-intensive.

It is important to point out that the series in the chart are GDP-shares while in the model $\alpha_{o}$ determines a cost-share in terms of gross output. It can be shown that if $g$ is the GDP-share, then $\alpha_{o}=g /(1+g)$. For this exercise, we calculated the average GDP-share for firm spending over the Great Moderation period (1986-2015), which turns out to be 0.02. The cost-share is then equal to 0.0196 .

Next we turn to the steady state values of the variables. There is some leeway in how to normalize the variables. A particularly convenient normalization for this model is to set $y, n$ and $z^{n}$ equal to 1 . This ensures that $\alpha_{o}$ is equal to cost-share of oil and also allows the modeler to solve for the rest of the steady state by hand. The firm's first order condition for labor gives $w=1-\alpha_{o}$ while the first order condition for oil gives $p^{o} o=\alpha_{o}$. This implies that we can also normalize units for oil use, and we do so by setting $p^{o}=1$. The value of $o$ is then determined by our calibration of $\alpha_{o}$. The market clearing conditions then imply trivially that $c=y-p^{o} o$ and $o^{s}=o$. Using the

\footnotetext{
${ }^{14}$ An alternative approach is to jointly calibrate the shock parameters to match moments in the data, possible in conjunction with calibrating some other parameters. One could also estimate all of the parameters using maximum likelihood or Bayesian methods.

${ }^{15}$ See Table ET1 of the U.S. Energy Information Administration's 2015 State Energy Data report.

${ }^{16}$ See specifically "Motor vehicle fuels, lubricants and fluids" and "Fuel oil and other fuels."
} 
steady-state production function, one can then show that $z^{o}=1 / o$.

\subsection{Impulse response functions}

We level linearize the model around the initial steady state and solve it using Dynare. Matlab code can be found online. Our main goal is to show how GDP and the price of oil respond to the two shocks in the model. We consider a negative oil supply shock and a positive labor-augmenting productivity shock. The latter is an aggregate supply shock, but from the perspective of the oil market it acts as a demand shock. We standardize the size of the shocks so that in each case they boost the price of oil by 10 percent.

Figure 4 plots the percent-deviations of the two variables from their steady states. The top row is the response of the price of oil while the bottom row is the response of GDP. The first column is for an oil supply shock while the second is the productivity shock. A negative oil supply shock reduces the supply of oil and drives up its relative price. As oil is an input into production, this raises costs for the firm, lowers the marginal product of labor and leads to a decline in non-oil GDP. On the other hand, a positive technology shock boosts the marginal product of labor and also raises the demand for oil. In this case, the price oil also rises but so does GDP.

A direct implication of the IRFs is that in the model economy the correlation between oil prices and economic activity will depend a lot upon the nature of the shocks. If oil supply shocks are large relative to productivity shocks then a negative correlation could certainly occur, and vice-versa. In small samples of time series the correlation could also depend upon the particular sequence of shocks. For example, if in a small window of time there were many large negative oil supply shocks, it would look like oil prices were negatively correlated with activity even if over longer periods of time the opposite correlation holds.

Obviously, these results are from a simple model with just two shocks. Other shocks could be introduced, each of which could potentially generate its own correlation between GDP and oil prices. Likewise, various extensions to the model could allow for a more richer analysis. For example, explicitly modeling the rest of the world would allow one to make statements about how different foreign shocks affect domestic GDP and oil prices. The literature review that follows provides many examples of papers with more complicated models that have extended the basic framework in numerous directions.

\subsection{Literature review}

\section{Oil prices and economic activity}

A large part of the DSGE literature has considered the potential importance of energy and energy prices for economic activity. The first work focused exclusively on this issue was Kim and 
Loungani (1992), which was aptly titled "The role of energy in real business cycle models." This work extended the RBC model of Hansen (1985) to include energy as an input to the production function. One of the major questions in Kim and Loungani (1992) was to what extent exogenous energy price shocks could generate volatility in output, thereby reducing the reliance of the RBC model on technology shocks. The main finding was that while energy price shocks could increase output volatility, price shocks alone could not be the main driver of fluctuations in output. Dhawan and Jeske (2008a) later extended Kim and Loungani (1992) by adding a consumer durable good and differentiating between firm and household demand for energy but reached a similar conclusion. Indeed, the results in Dhawan and Jeske (2008b) suggest that differentiating between household and firm energy use, while holding fixed the total amount of energy use, will actually reduce the ability of energy price shocks to generate volatility. A recent work, Balke and Brown (2018), estimates a DSGE model of the U.S. using data from 1991 to 2015 and finds a small elasticity of real GDP with respect to oil price shocks driven by foreign oil supply.

Rotemberg and Woodford (1996) present empirical evidence that oil price shocks generated large, persistent drops in U.S. value-added during the period of 1948 to 1980. They show that a model of imperfect competition can match this empirical finding, while a model of perfect competition, such as the one in Kim and Loungani (1992), has trouble doing so. Finn (2000) shows that a model of perfect competition extended to include capital utilization, where the utilization rate is tied to energy usage, can match the empirical findings in Rotemberg and Woodford (1996). Aguiar-Conraria and Wen (2007) show that a model with increasing returns to scale in production can explain the impact the oil price shock of 1973-1974 on output and investment.

\section{Oil prices and the Great Moderation}

A related line of research has investigated the quantitative importance of oil prices in explaining the Great Moderation. Leduc and Sill (2007) found that much of the decline in U.S. output volatility was due to a change in the behavior of TFP and oil supply shocks, rather than a change in monetary policy. Dhawan et al. (2010) showed that a negative statistical connection existed between energy prices and U.S. TFP until 1982. Through the lens of a DSGE model, they find that disappearance of this negative connection after 1982 can explain a significant fraction of the moderation in U.S. output. Nakov and Pescatori (2010) find that oil related factors play an important role in reducing output volatility, although they are not the most important factor. On the other hand, Bjornland et al. (Forthcoming), using a Markov Switching Rational Expectations NewKeynesian model, find that oil price volatility does not play a major role in explaining the Great Moderation.

\section{Changes in the effects of oil shocks}

Another line of research has used DSGE models to try and explain why the oil price shocks of the 1970s had larger impacts on the economy relative to the effects in the 2000s. Blanchard 
and Riggi (2013), building on the work of Blanchard and Galí (2009), show that a lower degree of real wage rigidity, better monetary policy and smaller oil cost and consumption-expenditure shares are important factors that have reduced the ability of oil prices to impact the economy. Katayama (2013) shows that some of the weaker effects of the post-1970 period can be explained by deregulation of the U.S. transportation sector in the early 1980s, improved energy efficiency and less persistent oil prices. In the model of Gavin et al. (2015), it is interactions between the tax code and inflation that led to the larger effects of the oil price increases in the 1970s. More specifically, they assume that during the 1970s oil prices boosted the Fed's inflation target, which increased the inflationary effects of an oil price shock and increased taxes on nominal capital gains. This created an additional, indirect negative impact on the economy as households reduced investment in the capital stock due to the higher taxes.

One finding from the recent empirical literature is that the oil price increases in the 2000s were driven primarily by global demand, and not oil supply shocks. ${ }^{17}$ Given this finding, it is less surprising that high oil prices were not associated with a slowdown in global activity: oil prices were high because the global economy was booming in the first place. A more subtle issue, though, is how that might have impacted the U.S. economy. In Blanchard and Riggi (2013), it is assumed that a shock to oil prices due to foreign demand affects the U.S. economy in a similar way to exogenous oil supply shocks. On the other hand, in the three-country DSGE model in Lippi and Nobili (2012), the impact on the U.S. economy from an oil price increase due to the rest of the world can depend upon the exact nature of the shock. In some cases it is negative, in others the impact is ambiguous despite the fact that oil prices are higher.

\section{Monetary policy and oil prices}

Another branch of the literature has used DSGE models to consider monetary policy responses to oil prices. Motivated by the discussions in Bernanke et al. (1997) and Hamilton and Herrera (2004), Leduc and Sill (2004) considered how different specifications of monetary policy rules affect the responses of output and inflation to oil price shocks. They find that a pre-1979 specification of a monetary policy rule exacerbates the impacts of an oil shock on inflation and output, relative to a post-1979 rule. Later, Bodenstein et al. (2008) looked at the optimal monetary policy response to an oil supply shock in a DSGE model with an exogenous supply of oil and nominal price and wage rigidities. They find that the optimal policy calls for a rise in core inflation to help mitigate the impacts of sticky nominal wages. Numerous papers have considered extensions to the two works just cited. In Nakov and Pescatori (2010), optimal monetary policy is considered in a model with a dominant oil producer. Kormilitsina (2011) looks at optimal policy in a medium-scale estimated DSGE model of the U.S. economy. Bodenstein et al. (2012) use a two-country DSGE model to discuss how policy responses can vary depending upon the underlying structural shock that has

\footnotetext{
${ }^{17}$ See, for example, Kilian (2009) and Lippi and Nobili (2012).
} 
affected oil prices. Natal (2012) discuss the implications of a distorted steady state for optimal policy. Bodenstein et al. (2013) consider the interaction between oil supply shocks and the zero lower bound constraint. Plante (2014a) considers optimal policy in a model where oil supply and (aggregate) productivity shocks affect the price of oil.

\section{Other topics}

The literature review so far has focused on research looking at the economic impacts of oil prices or monetary policy issues related to oil. But DSGE models have also been used to explore a number of other topics, particularly in international macroeconomics but also in areas related to energy consumption and energy policy. Here, we provide a quick overview of some important works. For brevity's sake, we do not discuss the results of these papers in any detail. Backus and Crucini (2000) looked at how oil prices impact the terms of trade for a handful of OECD countries. Bodenstein et al. (2011) use a two-country DSGE model to consider how changes in oil prices affect trade balances, real exchange rates and other macroeconomic variables. Lippi and Nobili (2012) use the model of Backus and Crucini (2000) to help motivate a VAR model of the oil market that is identified using sign restrictions. The role of fiscal policy in a small oil-exporting country is considered in Pieschacon (2012). Nakov and Nuno (2013) introduce a three-country DSGE model where Saudi Arabia is modeled as a dominant oil producer. Using the same model, Manescu and Nuno (2015) consider the impact of the shale oil boom on oil markets. Bergholt et al. (In press) consider the importance of oil prices for business cycles in a small oil-exporting country. Arezki et al. (2017) use discoveries of giant oil fields as an example of news shocks in a smallopen economy setting. Several papers have looked at issues related to energy policy and energy use. Atkeson and Kehoe (1999) explore the ability of putty-putty and putty-clay models to match the low short-run and higher long-run price elasticities of demand for energy seen in the data. The long-term macroeconomic impacts of consumer subsidies on fossil fuels are investigated in Plante (2014b) using a small-open economy model. That work is extended in Balke et al. (2015), which uses a two-country DSGE model to consider the global impacts those types of subsidies have on oil prices and the global economy. Atalla et al. (2017) show how prices and policies affect the energy mixes of several OECD countries through the lens of a DSGE model.

\section{References}

AAstveit, K. A. (2014): "Oil price shocks in a data-rich environment," Energy Economics, 45, 268-279.

Aastveit, K. A., H. C. BuøRnland, And L. A. Thorsrud (2015): "What drives oil prices? Emerging versus developed economies," Journal of Applied Econometrics, 30, 1013-1028. 
AGUiAR-CONRARIA, L. AND Y. WEN (2007): "Understanding the large negative impact of oil shocks," Journal of Money, Credit and Banking, 39, 925-944.

AREZKI, R., V. A. RAMEY, AND L. ShEnG (2017): "News shocks in open economies: Evidence from giant oil discoveries," The Quarterly Journal of Economics, 131, 103-155.

Atalla, T., J. Blazquez, L. C. Hunt, And B. Manzano (2017): "Prices versus policy: An analysis of the drivers of the primary fossil fuel mix," Energy Policy, 106, 536-546.

AtKeson, A. And P. J. Kehoe (1999): "Models of Energy Use: Putty-Putty versus Putty-Clay," The American Economic Review, 89, 1028-1043.

BACHMEIER, L. (2013): "Identification in models of gasoline pricing," Economics Letters, 120, $71-73$.

BACHMEIER, L., Q. LI, AND D. LIU (2008): "Should oil prices receive so much attention? An evaluation of the predictive power of oil prices for the us economy," Economic Inquiry, 46, 528-539.

BACHMEIER, L. J. AND I. CHA (2011): "Why don't oil shocks cause inflation? Evidence from disaggregate inflation data," Journal of Money, Credit and Banking, 43, 1165-1183.

BACKus, D. K. AND M. J. CRUCINI (2000): "Oil prices and the terms of trade," Journal of International Economics, 50, 185-213.

Balke, N., M. Plante, And M. K. YuCel (2015): "Fuel subsidies, the oil market and the world economy," The Energy Journal, 36.

BALKE, N. S. AND S. P. BROWN (2018): “Oil supply shocks and the U.S. economy: An estimated DSGE model," Energy Policy, 116, 357-372.

BALKe, N. S., S. P. BROWN, AND M. K. YÜCEL (2002): "Oil price shocks and the US economy: Where does the asymmetry originate?" The Energy Journal, 27-52.

BARSKY, R. B. AND L. KILIAN (2001): "Do we really know that oil caused the great stagflation? A monetary alternative," NBER Macroeconomics annual, 16, 137-183.

BAUMeister, C. AND J. D. HAMilton (2017): "Structural Interpretation of Vector Autoregressions with Incomplete Identification: Revisiting the Role of Oil Supply and Demand Shocks," Working paper.

BAumeister, C. AND L. KiLIAN (2016): "Lower oil prices and the US economy: Is this time different?" Brookings Papers on Economic Activity, 2016, 287-357.

Baumeister, C., L. Kilian, AND X. Zhou (2017): "Is the Discretionary Income Effect of Oil Price Shocks a Hoax?" .

Baumeister, C. AND G. PeErsman (2013): "Time-varying effects of oil supply shocks on the US economy," American Economic Journal: Macroeconomics, 5, 1-28.

Bergholt, D., V. H. LARsen, And M. Seneca (In press): "Business cycles in an oil economy," Journal of International Money and Finance. 
BERnANKE, B. S. (1983): "Irreversibility, uncertainty, and cyclical investment," The Quarterly Journal of Economics, 98, 85-106.

Bernanke, B. S., M. Gertler, And M. WATson (1997): "Systematic monetary policy and the effects of oil price shocks," Brookings papers on economic activity, 1997, 91-157.

BJornland, H. C., V. H. LARsen, And J. MAIH (Forthcoming): "Oil and macroeconomic (in)stability," American Economic Journal: Macroeconomics.

BlanCHARD, O. (2006): "Neoclassical Synthesis," .

Blanchard, O. J. AND J. GALÍ (2009): “The Macroeconomic effects of oil shocks: Why are the 2000s so different from the 1970s?" in International Dimensions of Monetary Policy, ed. by J. Galí and M. Gertler, Chicago: University of Chicago Press.

Blanchard, O. J. AND M. RigGi (2013): "Why are the 2000s so different from the 1970s? A structural interpretation of changes in the macroeconomic effects of oil prices," Journal of the European Economic Association, 11, 1032-1052.

BLINDER, A. S. AND J. B. RUDD (2012): "The supply-shock explanation of the Great Stagflation revisited," in The Great Inflation: The rebirth of modern central banking, University of Chicago Press, 119-175.

Bodenstein, M., C. J. ErCeg, And L. Guerrieri (2008): “Optimal monetary policy with distinct core and headline inflation rates," Journal of Monetary Economics, 55, S18-S33.

- (2011): “Oil shocks and external adjustment," Journal of International Economics, 83, $168-184$.

Bodenstein, M., L. Guerrieri, And C. J. Gust (2013): “Oil shocks and the zero lower bound on nominal interest rates," Journal of International Money and Finance, 32, 941-967.

Bodenstein, M., L. GuerRieri, And L. Kilian (2012): "Monetary policy responses to oil price fluctuations," IMF Economic Review, 60 (4), 471-504.

Burbidge, J. AND A. HARRISON (1984): “Testing for the Effects of Oil-Price Rises Using Vector Autoregressions," International Economic Review, 25, 459-484.

Caldara, D., M. Cavallo, And M. M. Iacoviello (2016): "Oil price elasticities and oil price fluctuations," Working paper.

CAstro, C., M. Jerez, And A. BARGe-Gil (2016): "The deflationary effect of oil prices in the euro area," Energy Economics, 56, 389-397.

CHEn, S.-S. (2009): “Oil price pass-through into inflation,” Energy Economics, 31, 126-133.

Clark, T. E. AND S. J. TERry (2010): "Time variation in the inflation passthrough of energy prices," Journal of Money, credit and Banking, 42, 1419-1433.

CUÑAdo, J. AND F. P. DE GRACIA (2003): "Do oil price shocks matter? Evidence for some European countries," Energy economics, 25, 137-154.

DAVIS, S. J. AND J. HALTIWANGER (2001): "Sectoral job creation and destruction responses to oil price changes," Journal of monetary economics, 48, 465-512. 
De Gregorio, J., O. Landerretche, C. Neilson, C. Broda, And R. Rigobon (2007): "Another pass-through bites the dust? Oil prices and inflation [with comments]," Economia, 7, 155-208.

DHAWAN, R. AND K. JESKE (2008a): "Energy price shocks and the macroeconomy: The role of consumer durables," Journal of Money, Credit and Banking, 40 (7), 1357-1377.

(2008b): "What determines the output drop after an energy price increase: Household or firm energy share?" Economics Letters, 101, 202-205.

DhawAn, R., K. Jeske, And P. Silos (2010): "Productivity, energy prices and the great moderation: A new link," Review of Economic Dynamics, 13, 715-724.

EdELSTEIn, P. AND L. KiliAn (2009): "How sensitive are consumer expenditures to retail energy prices?" Journal of Monetary Economics, 56, 766-779.

FARrell, D. AND F. Greig (2015): "How Falling Gas Prices Fuel the Consumer: Evidence from 25 Million People,” Working Paper, JP Morgan Chase \& Co Institute., 28, 2016.

FERderer, J. (1996): "Oil Price Volatility and Macroeconomy: A solution to the asymmetry Puzzle," Journal of Macroeconomics, 18, 1-26.

FInN, M. G. (2000): "Perfect Competition and the Effects of Energy Price Increases on Economic Activity," Journal of Money, Credit and Banking, 32 (3), 400-416.

GALÍ, J. AND M. GeRTLER (2007): "Macroeconomic modeling for monetary policy evaluation," Journal of economic perspectives, 21, 25-46.

Gavin, W. T., B. D. Keen, And F. E. Kydland (2015): "Monetary policy, the tax code, and the real effects of energy shocks," Review of Economic Dynamics, 18, 694-707.

Gelman, M., Y. Gorodnichenko, S. Kariv, D. Koustas, M. D. Shapiro, D. SilverMAN, AND S. TADELIS (2016): "The Response of Consumer Spending to Changes in Gasoline Prices," Tech. rep., National Bureau of Economic Research.

Hamilton, J. D. (1983): “Oil and the Macroeconomy Since World War II," Journal of Political Economy, 228-248.

(1985): "Historical Causes of Postwar Oil Shocks and Recessions," Energy Journal, 97116.

Hamilton, J. D. (1988): "A Neoclassical Model of Unemployment and the Business Cycle," Journal of Political Economy, 96, 593-617.

- (1996): “This is What Happened to the Oil Price Macroeconomy Relation," Journal of Monetary Economics, 38, 215-220.

(2003): "What Is an Oil Shock?" Journal of Econometrics, 113, 363-398.

(2008): “Oil and the Macroeconomy," In New Palgrave Dictionary of Economics, 2nd edition, edited by Steven Durlauf and Lawrence Blume, Palgrave McMillan Ltd., 2008. (2011): "Nonlinearities and the Macroeconomic Effects of Oil Prices," Macroeconomic Dynamics, 15, 364-378. 
(2016): “Comment on Lower Oil Prices and the U.S. Economy: Is This Time Different?" Brookings Papers on Economic Activity, 337-343.

Hamilton, J. D. And A. M. Herrera (2004): "Oil Shocks and Aggregate Macroeconomic Behavior: The Role of Monetary Policy," Journal of Money, Credit and Banking, 36, 265-286.

HAnsen, G. (1985): "Indivisible labor and the business cycle," Journal of Monetary Economics, $16,309-327$.

Herrera, A. M. AND M. B. KARAKI (2015): "The effects of oil price shocks on job reallocation," Journal of Economic Dynamics and control, 61, 95-113.

Herrera, A. M., L. G. Lagalo, AND T. WADA (2011): “Oil price shocks and industrial production: Is the relationship linear?" Macroeconomic Dynamics, 15, 472-497.

- (2015): "Asymmetries in the response of economic activity to oil price increases and decreases?” Journal of International Money and Finance, 50, 108-133.

Herrera, A. M. And E. PeSAVEnto (2009): "Oil price shocks, systematic monetary policy, and the Great Moderation," Macroeconomic Dynamics, 13, 107-137.

HoOKeR, M. A. (1996): "What happened to the oil price-macroeconomy relationship?" Journal of monetary Economics, 38, 195-213.

(2002): "Are oil shocks inflationary?: Asymmetric and nonlinear specifications versus changes in regime," Journal of Money, Credit, and Banking, 34, 540-561.

JORDÀ, Ò. (2005): "Estimation and inference of impulse responses by local projections," American economic review, 95, 161-182.

KATAYAmA, M. (2013): "Understanding the large negative impact of oil shocks," Journal of Money, Credit and Banking, 39, 925-944.

Kilian, L. (2009): "Not all oil price shocks are alike: Disentangling demand and supply shocks in the crude oil market," American Economic Review, 99, 1053-69.

- (2014): "Oil price shocks: Causes and consequences," .

KILIAN, L. AND D. P. MURPHY (2012): "Why agnostic sign restrictions are not enough: understanding the dynamics of oil market VAR models," Journal of the European Economic Association, 10, 1166-1188.

Kilian, L. And C. Vega (2011): "Do energy prices respond to US macroeconomic news? A test of the hypothesis of predetermined energy prices," Review of Economics and Statistics, 93, 660-671.

KILIAN, L. AND R. J. VigfuSSON (2011a): "Are the responses of the US economy asymmetric in energy price increases and decreases?" Quantitative Economics, 2, 419-453.

(2011b): "Nonlinearities in the oil price-output relationship," Macroeconomic Dynamics, $15,337-363$.

- (2013): "Do oil prices help forecast us real gdp? the role of nonlinearities and asymmetries," Journal of Business \& Economic Statistics, 31, 78-93. 
- (2017): “The role of oil price shocks in causing US recessions," Journal of Money, Credit and Banking, 49, 1747-1776.

KIM, I.-M. AND P. LoungANi (1992): “The role of energy in real business cycle models," Journal of Monetary Economics, 29, 173-189.

Kormilitsina, A. (2011): “Oil price shocks and the optimality of monetary policy," Review of Economic Dynamics, 14, 199-223.

LEDUC, S. AND K. SILL (2004): “A Quantitative Analysis of Oil-price shocks, systematic monetary policy, and economic downturns," Journal of Monetary Economics, 51, 781-808.

- (2007): "Monetary policy, oil shocks and TFP: Accounting for the decline in US volatility," Review of Economic Dynamics, 10, 595-614.

LEE, K. AND S. Ni (2002): “On the Dynamic Effects of Oil Price Shocks A Study Using Industry Level Data," Journal of Monetary Economics, 49, 823-852.

LeE, K., S. Ni, AND R. RATTi (1995): “Oil Shocks and the Macroeconomy: The Role of Price Variability," Energy Journal, 16, 39-56.

LiPPI, F. AND A. NoBILI (2012): "Oil and the macroeconomy: A quantitative structural analysis," Journal of the European Economic Association, 10(5), 1059-1083.

LUCAS JR, R. E. (1976): "Econometric policy evaluation: A critique," in Carnegie-Rochester conference series on public policy, Elsevier, vol. 1, 19-46.

MANESCU, C. B. AND G. Nuno (2015): “Quantitative effects of the shale oil revolution,” Energy Policy, 86, 855-866.

MCCAndless, G. (2008): “The abcs of rbcs," Cambridge, Massachusetts, London: Harvard.

NAKov, A. AND G. Nuno (2013): "Saudi Arabia and the oil market," The Economic Journal, $123,1333-1362$.

NAkov, A. And A. Pescatori (2010): "Oil and the Great Moderation,” The Economic Journal, $120,131-156$.

NAtAl, J.-M. (2012): “Monetary Policy Response to Oil Price Shocks," Journal of Money, Credit and Banking, 44 (1), 53-101.

PeErsman, G. AND I. VAN Robays (2012): "Cross-country differences in the effects of oil shocks," Energy Economics, 34, 1532-1547.

PIEsChacon, A. (2012): "The value of fiscal discipline for oil-exporting countries," Journal of Monetary Economics, 59, 250-268.

Plante, M. (2014a): "How should monetary policy respond to changes in the relative price of oil? Considering supply and demand shocks," Journal of Economic Dynamics and Control, 44, $1-19$.

(2014b): "The long-run macroeconomic impacts of fuel subsidies," Journal of Development Economics, 107, 129-143. 
RAmeY, V. A. (2016): "Comment on Lower Oil Prices and the U.S. Economy: Is This Time Different?" Brookings Papers on Economic Activity, 343-351.

Rasche, R. H. And J. A. TAtum (1977): “Energy Resources and Potential GNP,” Federal Reserve Bank of St. Louis Review, 59, 10-24.

(1981): "Energy Price Shocks, Aggregate Supply, and Monetary Policy: The Theory and International Evidence," in Supply Shocks, Incentives, and National Wealth, Carnegie-Rochester Conference Series on Public Policy, ed. by K. Brunner and A. Meltzer, Amsterdam: NorthHolland, vol. 14.

Ravazzolo, F. and P. Rothman (2013): "Oil and US GDP: A Real-Time Out-of-Sample Examination," Journal of Money, Credit and Banking, 45, 449-463.

Rotemberg, J. J. AND M. Woodford (1996): "Imperfect Competition and the Effects of Energy Price Increases on Economic Activity,' Journal of Money, Credit and Banking, 28 (4), $549-577$. 

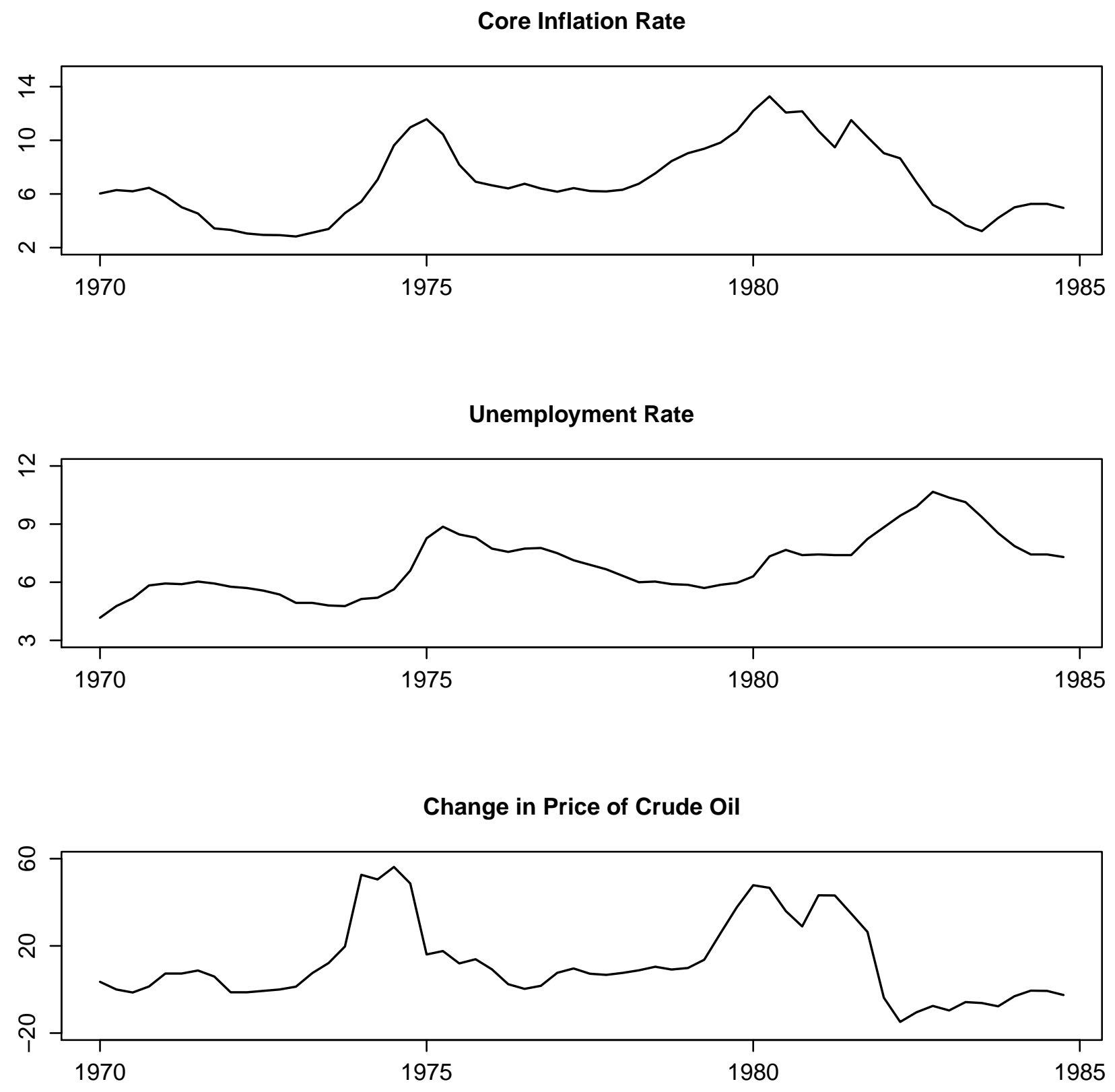

Figure 1: 


\section{Core Inflation Rate}

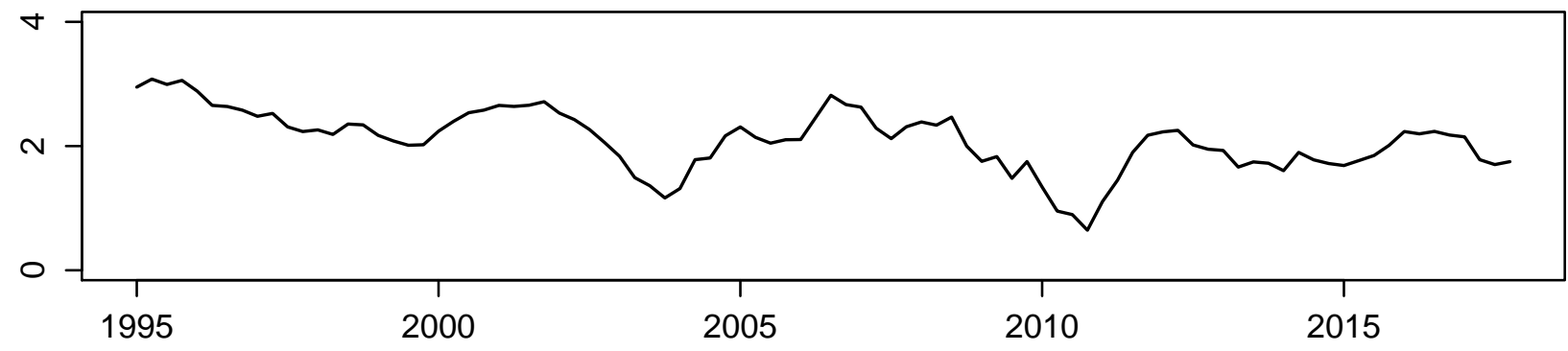

Unemployment Rate

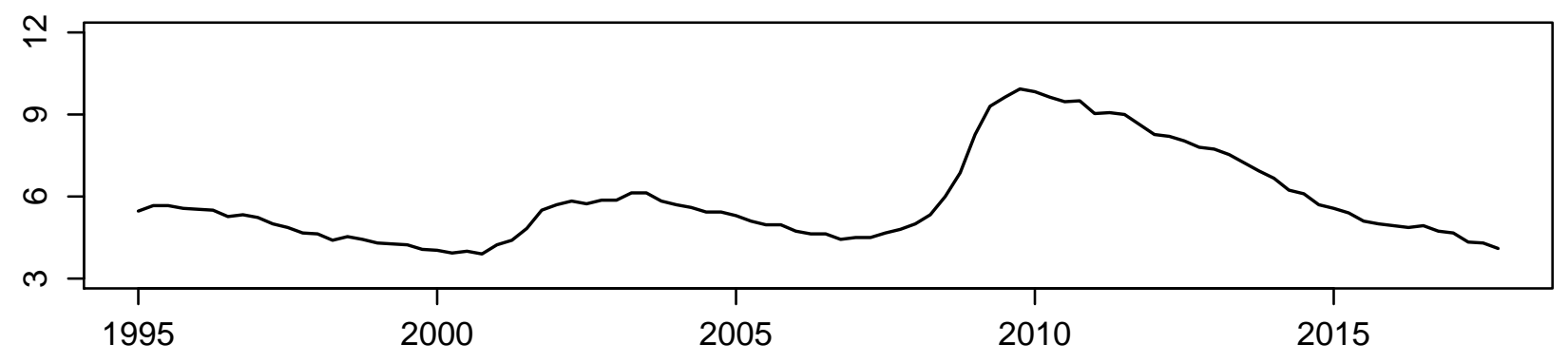

Change in Price of Crude Oil

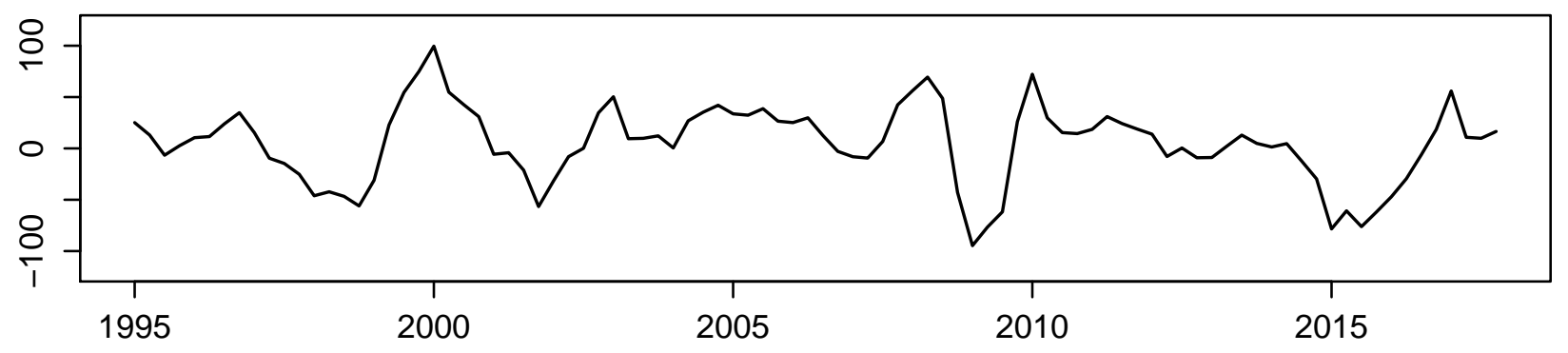

Figure 2: 


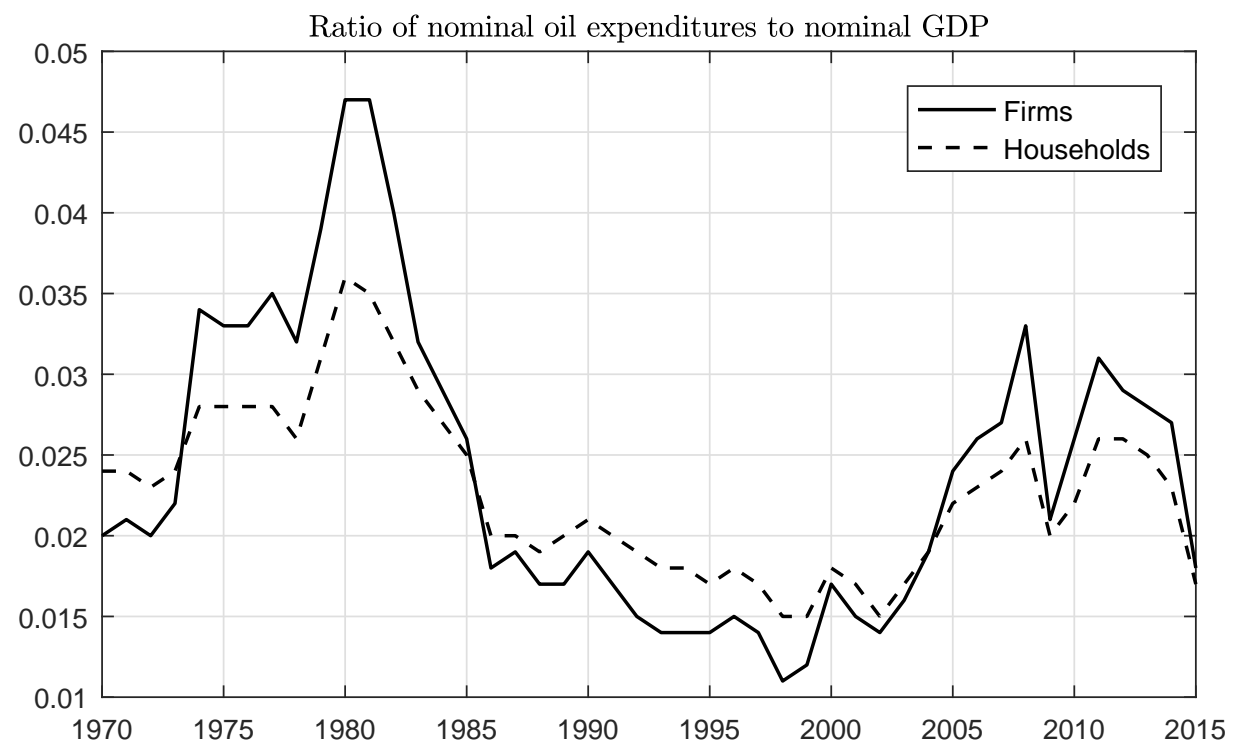

Figure 3: The ratio of nominal expenditures on petroleum products to nominal GDP. The dashed line is for household spending, the solid line for spending by firms. 

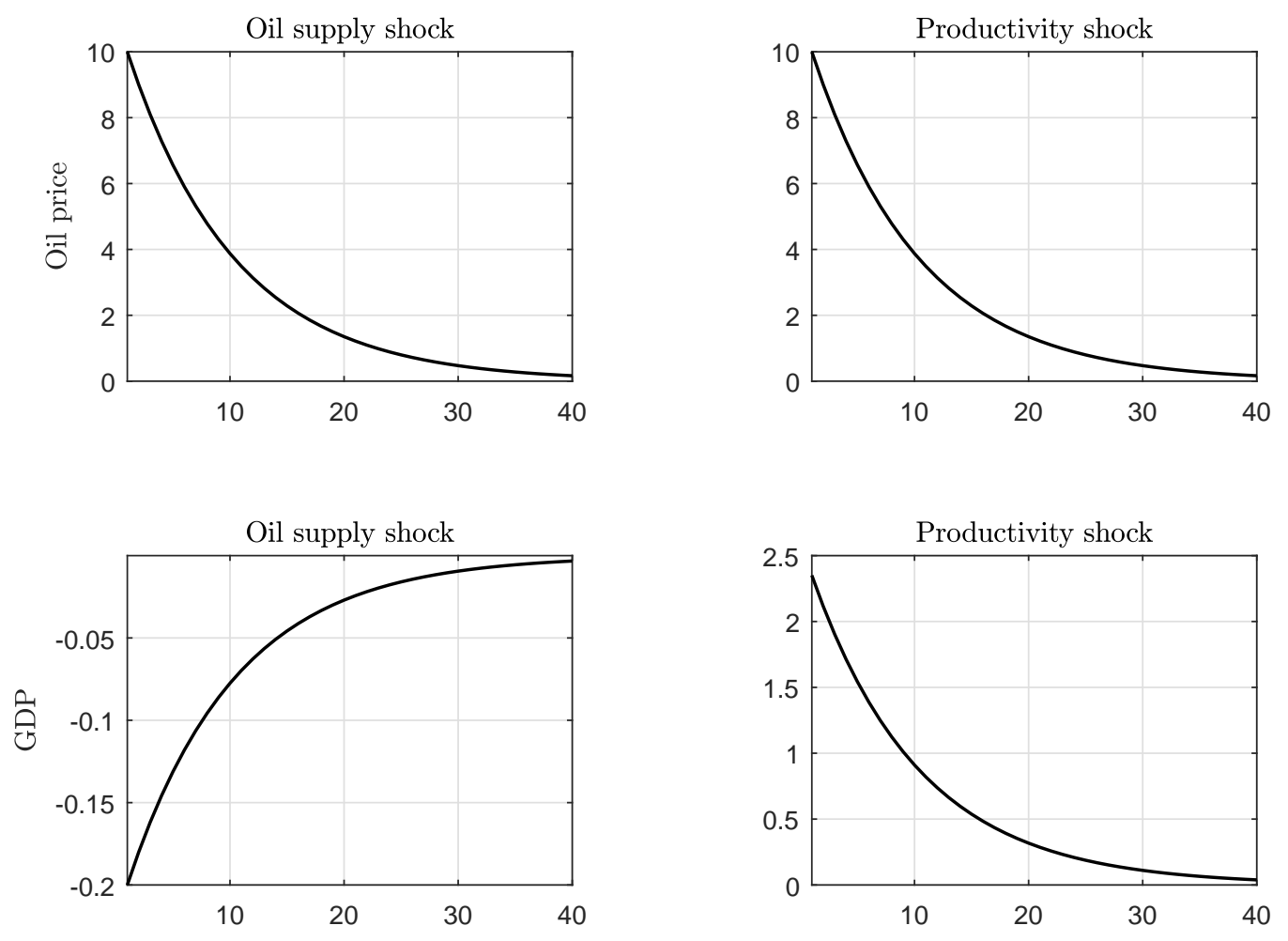

Figure 4: Impulse response functions to an oil supply shock (left-hand column) and a productivity shock (right-hand column). All figures show percent-deviations from steady-state values. 
Table 1: Estimated Coefficients on the Change in the Price of Oil

\begin{tabular}{lcccc}
\hline & $\widehat{\gamma}_{1}$ & $\widehat{\gamma}_{2}$ & $\widehat{\gamma}_{3}$ & $\widehat{\gamma}_{4}$ \\
\hline $1960-84$ & & & & \\
& -0.025 & -0.004 & -0.039 & $(-1.82)$ \\
$t-$ stat & $(-1.20)$ & $(-0.17)$ & $(-1.77)$ & \\
$1985-$ & & & & -0.001 \\
2017 & & & -0.004 & $(-0.68)$ \\
$t-$ stat & $(-0.57)$ & $(-0.84)$ & $(-0.12)$ & \\
\hline
\end{tabular}


Table 2: Estimated Coefficients on the Net Oil Price Increase

\begin{tabular}{lcccc}
\hline & $\widehat{\gamma}_{1}$ & $\widehat{\gamma}_{2}$ & $\widehat{\gamma}_{3}$ & $\widehat{\gamma}_{4}$ \\
\hline $1960-$ & & & \\
2017 & & & & \\
& -0.018 & -0.010 & -0.022 & -0.027 \\
$t-$ stat & $(-1.76)$ & $(-0.98)$ & $(-2.08)$ & \\
$1985-$ & & & & -0.020 \\
2017 & & & -0.012 & $(-2.16)$ \\
& -0.010 & -0.009 & $(-1.26)$ & \\
\hline
\end{tabular}

